Nr 2(59), 2019, s. 255-277

https://doi.org/10.12797/Politeja.16.2019.59.16

\author{
Marta BARANOWSKA ID \\ Uniwersytet Mikołaja Kopernika w Toruniu \\ mb1@law.umk.pl
}

\title{
DZIAŁALNOŚĆ PASTORA JAMESA \\ LAWSONA W NASHVILLE 1958-1960 \\ („NONVIOLENT WORKSHOP”, SIT-INS) - \\ STUDIUM PRZYPADKU WALKI \\ O ZMIANY SPOŁECZNO-POLITYCZNE
}

ABSTRACT The 1958-1960 Activities („Nonviolent Workshop”, Sit-ins) of Reverend James Lawson in Nashville - A Case Study in the Struggle for Sociopolitical Change

1958 in Nashville Reverend James Lawson and Reverend Kelly Miller Smith (NCLC) started organizing "nonviolent workshop". Lawson began teaching and training local residents in the techniques of the Gandhi's philosophy of direct nonviolent protest. On February 14 and 28, 1960, African American students launched their first full-scale sit-ins. Throughout the spring, the students conducted numerous sit-ins and boycotts. They suffered physical abuse and arrests, but held to the concept of Christian nonviolence. On April 19, after bombing damaged the home of $\mathrm{Z}$. Alexander Looby (defense counsel for the students), thousands of black and some white Americans marched to Nashville's City Hall. On May 10, 1960, Nashville became the first major city to begin desegregating its public facilities. The Nashville movement had been planned over several months, and served as a model for future demonstrations against segregation.

Key words: James Lawson, Nashville, Martin Luther King, non-violence, sit-in 


\section{WSTĘP}

Marsz na Waszyngton (March on Washington for Jobs and Freedom) z 28 sierpnia 1963 roku, w którym wzięło udział ponad dwieście tysięcy osób, by domagać się podniesienia płacy minimalnej i zniesienia segregacji rasowej, był jednym $\mathrm{z}$ istotniejszych wydarzeń w historii Stanów Zjednoczonych Ameryki po II wojnie światowej. Przemówienie pastora Martina Luthera Kinga, szczególnie słowa I have a dream, stało się wręcz symbolicznym hasłem w walce o równouprawnienie wszystkich ras na całym świecie. On sam stwierdzil, że to wydarzenie przejdzie do historii jako największa manifestacja na rzecz wolności $w$ dziejach naszego kraju ${ }^{1}$. Ruch na rzecz ustanowienia równych praw obywatelskich (The Civil Rights Movement) narodził się oczywiście wcześniej, zaczął przybierać na sile w latach 50 ., by w latach 60 . mieć już masowy wymiar, co doprowadziło do wprowadzenia konkretnych uregulowań prawnych ${ }^{2}$. Na pierwszy plan w tym czasie wysunięto postulat zniesienia segregacji rasowej, która pojawiła się po zniesieniu niewolnictwa, a została usankcjonowana wyrokiem Sądu Najwyższego w 1896 roku$^{3}$. Stał się on podstawą do przyjęcia wielu uregulowań faktycznie segregujących społeczeństwo według kryterium rasy i dyskryminujących Afroamerykanów w sferze publicznej, które określano mianem Jim Crow laws ${ }^{4}$. Aldon Morris podkreślał, że to był

M.L. King, Mam marzenie. I Have a Dream, 28 sierpnia 1963, [w:] tenże, „I have a dream”. Stowa zburzyty mury, przeł. G. Kość, G. Zawora, red. B. Szklarski, P. Średziński, Warszawa 2014, s. 119.

2 Dwa najważniejsze akty prawne, które znosiły segregację i zostały uchwalone pod wpływem aktywności ruchu na rzecz praw obywatelskich, w tym Marszu na Waszyngton, to uchwalony w 1964 roku The Civil Rights Act (pełny tytu1: An act to enforce the constitutional right to vote, to confer jurisdiction upon the district courts of the United States of America to provide injunctive relief against discrimination in public accommodations, to authorize the Attorney General to institute suits to protect constitutional rights in public facilities and public education, to extend the Commission on Equal Employment Opportunity, and for other purposes), [online] http://library.clerk.house.gov/reference-files/PPL_CivilRightsAct_ 1964.pdf, 17 IV 2017. W 1965 roku uchwalono drugi akt prawny: The Voting Rights Act (pełny tytu1: An act to enforce the fifteenth amendment of the Constitution of the United States, and for other purposes), [online] http://library.clerk.house.gov/reference-files/PPL_VotingRightsAct_1965.pdf, 17 IV 2017.

3 Dopóki funkcjonowało legalne niewolnictwo (w 1862 roku Abraham Lincoln wydał dekret prezydencki, Proklamację Emancypacji, która znosiła niewolnictwo na terenie tylko Skonfederowanych Stanów Ameryki - weszła w życie 1 stycznia 1863 roku; w 1865 roku Kongres przyjął XIII poprawkę do Konstytucji, która znosiła niewolnictwo na terenie całych Stanów Zjednoczonych na poziomie federalnym), nie była praktykowana segregacja rasowa, czarni i biali mogli uczęszczać do tych samych parków czy kościołów, oraz nie było praw, które by ją narzucały. Segregacja była wprowadzana stopniowo. W Karolinie Południowej już w 1877 roku zastosowano ją w środkach transportu publicznego. Praktyki te usankcjonowane zostały w 1896 roku wyrokiem Sądu Najwyższego w sprawie Plessy v. Ferguson. Zasada ta była określana mianem „oddzielni, ale równi” (separate but equal). Pełen tekst orzeczenia Plessy v. Ferguson, 163 U.S. 537 (1896) dostępny w zbiorze orzeczeń Sądu Najwyższego, [online] https:// supreme.justia.com/cases/federal/us/163/537/case.html, 17 IV 2017. Na marginesie należy dodać, że akty prawne już $w 1887$ roku zabraniaty dyskryminacji ws środkach transportu międzystanowego, a jednak nigdy nie zostaty opatrzone przepisami wykonawczymi. H. Zinn, Ludowa historia Stanów Zjednoczonych. Od roku 1492 do dziś, przeł. A. Wojtasik, Warszawa 2016, s. 582.

$4 \quad$ Szczególnie konsekwentnie polityka segregacji w sferze społecznej była prowadzona na południu USA. Dotyczyła ona zwłaszcza restauracji, barów, szpitali, szkół, ale też parków i miejsc zamieszkania. 
tylko jeden z elementów całego ustanowionego systemu dominacji białych. Określił go mianem tripartite system of (racial) domination, w ramach którego wyróżnił wyzysk ekonomiczny (economic exploitation), polityczne podporządkowanie i ubezwłasnowolnienie (political subjugation and disenfranchisement), społeczną opresję i segregację (social oppression and segregation $)^{5}$. Afroamerykanie byli więc ekonomicznie, politycznie i społecznie wykluczeni.

Celem artykułu jest podjęcie tematyki ruchów walczących z segregacją rasową i dyskryminacją w USA, a szczególnie przedstawienie, w jaki sposób zorganizowane grupy społeczne, również te wykluczone, mogą doprowadzić do przemian społecznych i politycznych. Uważam, że pomocne w analizie tych procesów mogą być studia nad wydarzeniami z lat 1958-60 w Nashville, w stanie Tennessee, które niczym w soczewce skupiają zjawiska wywołujące aktywność obywatelską i prowadzą do rewolucyjnych zmian. Wprawdzie to nie w Nashville organizowane były pierwsze akcje obywatelskiego nieposłuszeństwa, tylko w Baton Rouge, Luizjana, w 1953 roku czy w Montgomery, Alabama, w 1955 roku, ale właśnie tamtejsza organizacja została przez samego Kinga uznana za modelowąa ${ }^{6}$ Dodać należy, że duża część aktywistów odgrywających kluczowe

Całe dzielnice były więc często przeznaczone tylko dla jednej rasy. Oczywiście szpitale czy szkoły dla Afroamerykanów były finansowane w o wiele mniejszym wymiarze. Izabella Rusinowa wskazała, że Sam termin Jim Crow, określający pejoratywnie Murzyna na potudniu kraju, zacząt być używany po 1838 r., a po 1890 r. stat się nazwa segregacyjnych ustaw przeprowadzanych w zgromadzeniach stanów potudniowych. I. Rusinowa, Martin Luther KingJr. 1929-1968, Pultusk-Warszawa 2014, s. 90. Howard Zinn wskazał, że termin Jim Crow pochodził od tytułu prześmiewczej piosenki skomponowanej przez białego showmana Thomasa D. Rice'a w 1832 roku. Zob. H. Zinn, Ludowa historia..., s. 12. Jednak większość źródeł kulturoznawczych i dotyczących historii teatru amerykańskiego wskazuje na 1828 rok jako początek fenomenu Jim Crow. Kluczowy dla budowania tej postaci utwór Jump Jim Crow powstał w roku 1828 i od tego czasu, dzięki licznym tournée Rice’a, cieszył się ogromną popularnością. Zob. Jim Crow America. A Documentary History, red. C.M. Lewis, J.R. Lewis, Fayetteville 2009, s. 1-3; The Cambridge History of American Theatre, vol. 1: Beginnings to 1870, red. D.B. Wilmeth, Ch. Bigsby, Cambridge 1998, s. 359-360. Zdaniem Martina Luthera Kinga w ten sposób powstata nowa forma niewolnictwa. Zob. M.L. King, Strategia non-violence a sprawiedliwość rasowa, 6 lutego 1957, [w:] tenże, „I have a dream”..., s. 25.

5 Zob. A.D. Morris, The Origins of the Civil Rights Movement. Black Communities Organizing for Change, New York 1986, s. 1-4. Wprawdzie Sąd Najwyższy w 1944 roku zniósł prawo o supremacji białych, to jednak na Południu tylko nieliczni Afroamerykanie faktycznie mogli głosować. Nie było też prawie w ogóle czarnoskórych policjantów. Morris przytoczył też statystyki, według których średni dochód afroamerykańskiej rodziny na Południu był o $54 \%$ niższy niż białej. Było to rezultatem dużego bezrobocia dotykającego tę społeczność oraz faktu, że 75\% czarnych mężczyzn pracowało jako nisko wykwalifikowani pracownicy fizyczni, kobiety zaś głównie były pomocami domowymi. Wynikało to z braku faktycznej możliwości edukacji oraz niezatrudnienia na stanowiska lepiej płatne. Tamże. Należy dodać, że kobiety doświadczały jeszcze większej opresji, oprócz wymienionych trzech form, podobnie jak białe kobiety, także patriarchalizmu. Warto podkreślić, że ich aktywne zaangażowanie w The Civil Rights Movement przybierało wymiar walki o zmiany w sferze gender/race/class. Zob. B.M. Kuumba, Gender and Social Movements, Walnut Creek 2001, s. 31.

6 Nashville provided the best organized and best disciplined group in the whole southern student movement. King to Smith, 9 June 1960, [online] https://kinginstitute.stanford.edu/king-papers/documents/ kelly-miller-smith-1, 17 IV 2017. Więcej na temat historii walki z dyskryminacją Afroamerykanów od momentu decyzji Sądu Najwyższego z 1954 roku w sprawie Brown v. Board of Education of Topeka, Kansas aż do lat 90. XX wieku zob. H. Sitkoff, The Struggle for Black Equality, New York 1993. 
role w ruchu na rzecz praw obywatelskich wywodziła się właśnie z tego miasta ${ }^{7}$. Analiza tego zagadnienia wymagać będzie uwzględnienia dwóch zasadniczych wątków: po pierwsze, zrekonstruowane zostaną filozoficzne źródła poglądów Jamesa Lawsona, po drugie zaś - ich praktyczne aplikacje. Zwrócić należy uwagę, że w polskiej literaturze naukowej, oprócz ogólnych wzmianek, brak jest studium tego przypadku, warto więc się nad nim pochylićs.

\section{ORGANIZACJA WARSZTATÓW „NONVIOLENT WORKSHOP” W NASHVILLE PRZEZ PASTORÓW JAMESA LAWSONA I KELLY'EGO MILLERA SMITHA}

Osobą, która z powodzeniem walczyła z segregacją rasową w Nashville, był pastor Kościoła metodystów James Morris Lawson, Jr., urodzony 22 września 1928 roku w Uniontown w Pensylwanii. Christopher Richardson i Ralph Luker, opisując jego biografię, wskazali, że już w czasie studiów w Baldwin-Wallace College w Berea w stanie Ohio doszedł on do wniosku, że wszelkie formy przemocy oraz segregacja rasowa są niezgodne z etyką chrześcijańską ${ }^{9}$ W kwietniu 1951 roku odmówił odbycia służby wojskowej, ale - po długich przemyśleniach - ani nie powołał się na swoje przekonania (conscientious objector status), ani nie wnioskował o odroczenie czy to ze względu na chęć kontynuacji studiów, czy posługę pastorską, dlatego został skazany na 14 miesięcy więzienia. $\mathrm{Z}$ powodu sprowokowania zamieszek $\mathrm{w}$ federalnym więzieniu został przeniesiony do placówki penitencjarnej w Ashland w stanie Kentucky. Po zwolnieniu ukończył szkołę i został skierowany do pracy misyjnej w Indiach (pracowal jako duchowny w Hislop College Nagpur), gdzie przez trzy lata miał możliwość studiowania idei Mohandasa Karamchanda Gandhiego. W tym czasie również zapoznał się z relacjami z akcji bojkotu autobusów w Montgomery (Montgomery Bus Boycott), która niezwykle go zainspirowała ${ }^{10}$. Postanowil, że przed powrotem do domu uda się do Afryki, gdzie przez

Wśród najważniejszych liderów tego ruchu, wywodzących się spośród studentów szkolonych przez Jamesa Lawsona, wymienić należy: Johna Lewisa, Diane Nash, Jamesa Bevela, Mariona Barry’ego czy Bernarda Lafayette'a.

$8 \quad$ W polskiej literaturze naukowej biografię najbardziej znanego przywódcy tego ruchu opracowała Izabella Rusinowa, Martin Luther King Jr. 1929-1968. Mamy również kilka pozycji poświęconych filozofii obywatelskiego nieposłuszeństwa, z odwołaniem się do jego działalności, np. książkę Wojciecha Modzelewskiego, Walka bez użcia przemocy. Metody i idee, Warszawa 1983.

9 Ch.M. Richardson, R.E. Luker, Historical Dictionary of the Civil Rights Movement, Lanham 2014, s. 280-282.

10 W Montgomery aktywiści podjęli walkę o zniesienie segregacji rasowej w komunikacji miejskiej (pierwsze rzędy przeznaczone były dla białych, więc często pół autobusu było wolne, gdy Afroamerykanie musieli być stłoczeni w tylnych częściach pojazdu), która była jedną z form Jim Crow laws. Bojkot rozpoczął się jako bezpośrednia reakcja na aresztowanie 5 grudnia 1955 roku Rosy Parks, która wracając zmęczona z pracy, odmówiła ustąpienia miejsca w autobusie białemu mężczyźnie i została za to aresztowana. Wydarzenia te miały gwałtowny przebieg: wielu uczestników bojkotu trafiło do więzienia, biali zwolennicy segregacji podkładali bomby w kościołach, ostrzelano 
ponad miesiąc uczestniczył w spotkaniach z tamtejszymi liderami ruchów niepodległościowych. W USA zapisał się na początku 1957 roku do Oberlin College School of Theology w stanie Ohio, zamierzając zdobyć tytuł magistra. W tym samym roku, 7 lutego, po raz pierwszy spotkał się z Kingiem, który przybył tam, by wygłosić odczyt "The Montgomery Story”. Mieli oni okazję porozmawiać w czasie lunchu o swoich zainteresowaniach, między innymi poglądach Gandhiego, oraz uczestniczyli w panelu dyskusyjnym „The New Negro in the New South”. King był pod wrażeniem wiedzy i entuzjazmu Lawsona, dlatego zaczął namawiać go, by ten udał się na Południe i wsparł ruch na rzecz zniesienia segregacji rasowej ${ }^{11}$. Prośba ta wynikała z faktu, że King był bardzo obciążony licznymi obowiązkami i wykładami, a będąc niecały miesiąc wcześniej, 13 stycznia, w Nashville, widział, że potrzebna jest tam pomoc w organizacji ruchu ${ }^{12}$.

King faktycznie miał wielką siłę przekonywania, bo Lawson zgodnie z jego prośbą opuścił Oberlin College pod koniec 1957 roku i jako sekretarz terenowy Fellowship of Reconciliation (FOR) udał się na Poludnie ${ }^{13}$. W marcu 1958 roku zamieszkał w Nashville i w celu kontynuowania edukacji zapisał się do Vanderbilt University Divinity School. Rozpoczął też współpracę z pastorem Kościoła baptystycznego (First Baptist Church, Capitol Hill) Kellym Millerem Smithem, który przybył do Nashville w 1951 roku i od tego czasu stał się niezwykle aktywny w walce o prawa obywatelskie ${ }^{14}$. W 1955 roku wraz z 12 innymi rodzicami wniósł pozew przeciwko Nashville Board of Education, by ten implementował wyrok Sądu Najwyższego z 1954 roku w sprawie

drzwi domu Kinga. Bojkot oficjalnie został zakończony 20 grudnia 1956 roku, po tym gdy Sąd Najwyższy uznał prawo wprowadzające segregację w komunikacji miejskiej za niekonstytucyjne. Wśród przywódców akcji bojkotu na plan pierwszy wybił się King, który przybył do Montgomery w 1954 roku, by pracować jako pastor. Wśród organizatorów tego ruchu należy wymienić również Ralpha Abernathy'ego czy Bayarda Rustina, który, będąc w Indiach w 1948 roku, uczył się o metodach walki bez przemocy od przywódców ruchu Gandhiego i miał także możliwość spotkać się z samym Mahatmą przed jego zabójstwem. Więcej na temat tych wydarzeń zob. H. Zinn, Ludowa historia..., s. 583-584; I. Rusinowa, Martin Luther King Junior i wydarzenia w Montgomery, [w:] Amerykomania. Ksiega jubileuszowa ofiarowana profesorowi Andrzejowi Mani, t. 2, red. W. Bernacki, A. Walaszek, Kraków 2012, s. 721-760.

11 Zob. From James M. Lawson, 3 November 1958, Nyack N.Y., [w:] The Papers of Martin Luther King, Jr., vol. 4: Symbol of the Movement, January 1957-December 1958, red. C. Carson i in., Berkeley 2000, s. 524.

12 King w tym czasie jeździł po kraju z serią odczytów. Jeden z nich miał wygłosić właśnie w Nashville, niestety wydarzenie to zostało odwołane z powodu odkrycia atrapy bomby na chodniku przed kościołem, w którym miał wystąpić. Następnego wieczora zorganizowano zebranie, by rozważyć ten przypadek przemocy. W czasie modlitwy King, namawiając, by pomimo wszelkich okoliczności kierować się miłością, zasłabł. On sam bagatelizował to wydarzenie, ale świadkowie opisali później, że widać było, jak bardzo był on wyczerpany. Zob. Introduction, [w:] The Papers of Martin Luther King, Jr., vol. 4, s. 5.

13 Fellowship of Reconciliation to organizacja założona przez pacyfistów w 1915 roku i działająca do dziś, której motto brzmi: „Working for peace and justice through nonviolence since 1915”. Więcej na temat FOR, zob. Fellowship of Reconciliation, [online] http://www.forusa.org, 17 IV 2017.

14 Więcej na temat Kelly'ego Millera Smitha, zob. Smith, Kelly Miller, [w:] King Encyclopedia, The Martin Luther King, Jr., Research and Education Institute, [online] https://kinginstitute.stanford. edu/encyclopedia/smith-kelly-miller, 17 IV 2017. 
Brown v. Board of Education of Topeka, w którym uznano za niekonstytucyjne prawa sankcjonujące utrzymywanie oddzielnych szkół dla białych i czarnych uczniów ${ }^{15}$. Było to odrzucenie wcześniejszego orzecznictwa Sądu Najwyższego (wyroku z 1896 roku w sprawie Plessy v. Ferguson). Dzięki tym działaniom Joy, 6-letnia córka Smitha, była pierwszym afroamerykańskim dzieckiem, które w ramach integracji mogło zacząć uczęszczać do szkoły publicznej w Nashville w grudniu 1957 roku wraz z białymi uczniami. W 1956 roku Smith został przywódcą oddziału National Association for the Advancement of Colored People (NAACP) w Nashville, a w styczniu 1958 roku utworzył i został liderem The Nashville Christian Leadership Council (NCLC), który był afiliowany przy Southern Christian Leadership Conference (SCLC) ${ }^{16}$.

Lawson wspólnie ze Smithem w marcu 1958 roku zorganizowali pierwsze seminaria, które nazywali „nonviolent workshop” ${ }^{17}$. Odbywały się one w kościele Smitha, który w relacji Johna Lewisa, jednego z aktywistów z Nashville i późniejszego przewodniczącego Student Nonviolent Coordinating Committee (SNCC), był niczym „niebo” otwarte dla wszystkich chcących dyskutować o problemach w mieście ${ }^{18}$. Warto zwrócić uwagę, że to właśnie kościoły stały się ośrodkami organizacji The Civil Rights Movement, ponieważ Afroamerykanie byli wyrugowani ze sfery publicznej, a szkoły przeznaczone dla nich były uzależnione od państwowej administracji ${ }^{19}$. Należy podkreślić, że Nashville było wręcz idealnym miejscem na tego typu działalność, ponieważ w okolicy było kilka wyższych szkół dla Afroamerykanów (Fisk University, American Baptist Theological Seminary, Meharry Medical College, Tennessee University College), których studenci byli otwarci na aktywne włączenie się w walkę o równe prawa obywatelskie ${ }^{20}$.

15 Pełen tekst orzeczenia Brown v. Board of Education of Topeka, 347 U.S. 483 (1954) dostępny w zbiorze orzeczeń Sądu Najwyższego, [online] https://supreme.justia.com/cases/federal/us/347/ 483/case.html, 17 IV 2017.

16 NAACP to najstarsza organizacja założona przez białych i czarnych mieszkańców USA, działająca od 1909 roku (oficjalna rejestracja w 1910 roku), której celem była walka o prawa obywatelskie dla Afroamerykanów i edukacja wszystkich, by poprawić relacje międzyrasowe w społeczeństwie. Bezpośrednim bodźcem do stworzenia tej organizacji były zamieszki na tle rasowym w Springfield w stanie Illinois z 1908 roku, w których zginęło 7 osób. Warto zaznaczyć, że NAACP stawiało przede wszystkim na metody walki w postaci sporów sądowych i promowania konkretnych rozwiązań legislacyjnych. Więcej na temat NAACP zob. Nations Premier Civil Rights Organization, [online] https://www.naacp.org/nations-premier-civil-rights-organization/, 17 IV 2017; P. Sullivan, Charles Hamilton Houston and the NAACP Legal Strategy, [w:] Civil Rights since 1787. A Reader on the Black Struggle, red. J. Birnbaum, C. Taylor, New York-London 2000, s. 333-340. SCLC został założony na początku 1957 roku, a jego pierwszym przewodniczącym był M.L. King. Bezpośrednim bodźcem do stworzenia tej organizacji był Montgomery Bus Boycott. Więcej na temat historii tej organizacji, zob. SCLC History, Southern Christian Leadership Conference, [online] http://nationalsclc.org/aboutus/history/, 17 IV 2017.

17 Zob. A.D. Morris, The Origins..., s. 190.

18 Zob. tamże, s. 175.

19 E.F. Frazier, The Negro Church in America, New York 1963, s. 43.

20 Zob. A.D. Morris, The Origins..., s. 176. 


\section{WYKŁADY JAMESA LAWSONA W RAMACH „NONVIOLENT WORKSHOP”}

James Lawson prowadził wykłady w ramach „nonviolent workshop”, na których wykładał filozofię i taktykę walki bez przemocy ${ }^{21}$. W liście z 3 listopada 1958 roku skierowanym do Kinga pisał, że jedynie ta metoda oraz zjednoczenie może doprowadzić ich do realizacji celów, przede wszystkim zniesienia segregacji rasowej ${ }^{22}$. Ten cel, jak relacjonowali uczestnicy warsztatów, zapierał im dech w piersiach, bo w Nashville, które było posegregowane jak społeczeństwo w Republice Południowej Afryki w czasie apartheidu, wydawało się to niemożliwe ${ }^{23}$.

Podstawą światopoglądu Lawsona była myśl chrześcijańska, szczególnie nauczanie o miłości. Na szkoleniach wskazywał on na wzór osobowy Jezusa Chrystusa, który zmieniał świat siłą miłości, to nią zwyciężał zło. Szczególnie trudny w realizacji jest nakaz o miłowaniu nieprzyjaciół z Ewangelii według świętego Mateusza, stąd też wiele uwagi poświęcano mu na wykładach. Nawiązywał do niego nieustannie również King w licznych kazaniach i wystąpieniach. Podkreślał, że nie można go traktować jako hiperbolę czy wyraz niepraktycznego idealizmu, ponieważ to właśnie taka postawa umożliwia przetrwanie cywilizacji2 ${ }^{24}$. Wskazywał, że nienawiść wywołuje taką samą reakcję drugiej strony, w rezultacie czego zło rozprzestrzenia się w świecie i dosięga coraz więcej ludzi. Lawson w jednym z wywiadów, w którym opowiadał o prowadzonych przez siebie warsztatach, tłumaczył, że nienawiść bardzo szybko przeradza się w przemoc i ma prostą dynamikę - wywołuje reakcję drugiej strony w postaci: sprawię, że będziesz cierpiał bardziej. W ten sposób nakręca się spirala przemocy, która nie ma końca ${ }^{25}$. Należy więc zrozumieć, że taka postawa wywołuje tylko chaos i zniszczenie, nie ma ona w sobie żadnego potencjału twórczego. Przemoc nie rozwiazuje żadnych problemów spotecznych; po prostu stwarza nowe i bardziej skomplikowane ${ }^{26}$. W dodatku nienawiść ma negatywny wpływ nie tylko na osobę, która doświadcza jej skutków, ale również degeneruje naturę

21 Lawson miał bez wątpienia dar przemawiania i argumentowania. Już w czasach szkolnych, w 1946 roku, został mistrzem debat dotyczących bieżącej polityki. Zob. Ch.M. Richardson, R.E. Luker, Historical Dictionary..., s. 279.

22 I have been convinced for nearly 12 years now that the only hope for the Negro in this country is a genuine movement of non-violence which reflects many of the characteristics of the Montgomery boycott and which strikes not only at the fear of the Negro but also at the power structure of the nation which continue to perpetuate social injustice. If this is to happen it will be because of the ministry uniting as one body and giving initiative leadership to the countless number of Negroes who urgently want such leadership. From James M. Lawson, 3 November 1958, Nyack N.Y., [w:] The Papers of Martin Luther King, Jr., vol. 4, s. 524.

23 Zob. A Force More Powerful (polski tytul: Sita bez przemocy), documentary film, written \& produced by Steve York, release 1999 and 2000, York Zimmerman INC\&WETA, Washington, DC.

24 Zob. M.L. King, Mitujcie nieprzyjaciót waszych, 17 listopada 1957, [w:] tenże, „I have a dream”..., s. 77-88.

25 Zob. A Force More Powerful.

26 M.L. King, Strategia non-violence..., s. 27. 
tego, kto nienawidzi, może prowadzić do zachowań patologicznych ${ }^{27}$. Odnosiło się to również do samej opartej na przemocy i poniżaniu segregacji rasowej, która miała jego zdaniem - szkodliwy wptyw zarówno na osobę poddawana segregacji, jak i osobę ja stosująca. Tej drugiej dawata fatszywe poczucie wyższości, tej pierwszej fatszywe poczucie niższości $i^{28}$. Tylko odrzucenie nienawiści i przemocy może uratować cywilizację i dać nadzieję na stworzenie lepszego, sprawiedliwszego świata. Należy, kierując się nauką Jezusa, uczynić miłość podstawą swego życia. Do tego potrzebna jest wielka siła, bo przeciwstawiając się stereotypom, Lawson wskazywał, że to właśnie nienawiść jest przejawem słabości, najłatwiejszym, bezrefleksyjnym rozwiązaniem doraźnych problemów. Miłość natomiast, szczególnie miłość nieprzyjaciół, wymaga przezwyciężenia swych naturalnych odruchów (oddać, gdy mnie biją) i uświadomienia sobie prawd wiary, by żyć zgodnie z nauczaniem Jezusa. Miłość nie charakteryzuje więc ludzi słabych, tylko silnych, którzy mają odwage stawić czoto przeciwnikom, którzy mają odwage stawić czoto przemocy, nie uciekając się do przemocy ${ }^{29}$. Warto przywołać słowa Kinga o miłości, które stanowily jedną z podstaw filozofii nauczanej na „nonviolent workshop”: W ostatecznej analizie mitość nie jest sentymentalnym, ckliwym uczuciem. Nie o tym mówimy. Mitość to twórcza, wyrozumiata sita. To okazywanie życzliwości wszystkim ludziom. To odmowa pokonania jednostki. Kiedy osiagniesz ten stopień mitości w catej jej krasie i mocy, będziesz dążyt wytacznie do pokonania ztych systemów. Będziesz mitowaćjednostki, które sq̨ ofiarami wadliwego systemu, jednocześnie starając się z nim walczy co $^{30}$.

Wcielanie w życie nakazu miłości także nieprzyjaciół wymaga w pierwszej kolejności przyjrzenia się sobie, zwrócenia uwagi na swoje wady, mogące wywoływać niechęć innych. Trzeba zmiany zacząć od siebie. Następnie istotne jest zrozumienie, że w każdym człowieku jest pierwiastek dobra, to, co religia nazywa „obrazem Boga”. King postrzegał ludzką naturę jako po trosze schizofreniczna, która składa się ze ścierających się ze sobą pierwiastków dobra i zła. W najlepszych z ludzi jest więc także pierwiastek zła, jak i w najgorszych - dobra. Dzięki uświadomieniu sobie, jacy jesteśmy, staniemy się otwarci na siebie i będziemy mogli zbudować nową jakość we wzajemnych relacjach. Pamiętać również należy, że Bóg kocha wszystkie swoje dzieci, a zadaniem chrześcijanina jest postępowanie według wskazanego przez niego wzoru ${ }^{31}$. Z nauk Jezusa płynie więc przesłanie, że nic nie usprawiedliwia nienawiści i przemocy.

7 Psychologowie i psychiatrzy mówia nam dzisiaj, że im bardziej nienawidzimy, tym większe poczucie winy budujemy w sobie. Podświadomie ttumimy lub świadomie wytaczamy pewne uczucia. Uczucia te nawarstwiaja się $w$ naszej podświadomości i wywotuja tragiczne, neurotyczne reakcje. Możliwe, że u podtoża nerwic występujacych u wielu osób, które borykają się z życiem, leży jakaś forma nienawiści. Tenże, Mitujcie nieprzyjaciót waszych..., s. 84.

Tenże, Przemowa w trakcie Wielkiego Marszu w Detroit, 23 czerwca 1963, [w:] tenże, „I have a dream”..., s. 110.

Tamże, s. 112.

M.L. King, Mitujcie nieprzyjaciót waszych..., s. 81.

31 King wskazal, że w języku greckim istnieją trzy słowa na określenie miłości: eros, czyli miłość estetyczna, filia, oznaczająca przywiązanie między przyjaciółmi, oraz agape. Agape to więcej niż eros; agape to więcej niż filia; agape to wyrozumiata, twórcza, odkupieńcza sita zyczliwa dla wszystkich ludzi. Jest to taka mitość, która nie szuka niczego w zamian. To mitość przepetniająca; teologowie nazywaja ja mitościa 
Postawa miłości każdego bliźniego jest punktem wyjścia, by móc zmieniać system, który segreguje i dyskryminuje jednostki i grupy. King wskazał, że istnieją trzy sposoby przezwyciężenia niesprawiedliwego systemu. Pierwszy to odwołanie się do przemocy i nienawiści, ale jak argumentował, to rozwiązanie nie ma szans wywołać pozytywnych skutków i żaden chrześcijanin miłujący Boga nie może po niego sięgać. Drugim jest bierność, przyzwyczajenie do swej sytuacji. Również to nie jest dobrym rozwiąaniem, ponieważ brak wspótdziatania ze ztem jest takim samym obowiazkiem moralnym, jak wspótdziatanie $z$ dobrem ${ }^{32}$. Za jedynie słuszną drogę uznał on zorganizowanie masowego pokojowego sprzeciwu. W kazaniu wygłoszonym w kościele baptystów w Montgomery przywołał rozważania Napoleona, który stwierdzil, że zarówno on, jak i Aleksander, Cezar czy Karol Wielki zbudowali wielkie imperia oparte na przemocy i one upadty. Jezus dat początek imperium, którego fundamentem jest mitość i po dziś dzień miliony sa gotowe za Niego umrzeci3. Miłość, o której mówił zarówno King, jak i Lawson nie polega na bierności, lecz jest to aktywna postawa dążąca do zmiany świata. Przywoływali oni ewangeliczny wzór nadstawiania drugiego policzka, który interpretowali właśnie jako zalecenie, by nie dążyć do tego, aby pokonać nieprzyjaciela, lecz poprzez okazanie w takiej sytuacji pokory i wyrozumiałości przemówić do niego za pomocą siły miłości. Tylko odrzucając pokusę upokorzenia drugiego człowieka, można przeciągnąć go na swoją stronę i w przyszłości zbudować z nim relację opartą na miłości i zrozumieniu, która będzie podstawą wspólnoty chrześcijańskiej. King przestrzegal, że nie wolno nam wykorzystywać rodzacej się wolności i rosnacej sity w naszych relacjach z biatą mniejszościa. [...] nie możemy paść ofiara filozofii supremacji czarnych ${ }^{34}$. Dlatego jasno zadeklarowat: Mituję was. Prędzej umrę, niz was znienawidzę. Jestem tak gtupi, że wierze, iz dzięki potędze mitości ludzie najbardziej zaciekli przejda odnowę. Wtedy znajdziemy sie $w$ Królestwie Bożym ${ }^{35}$.

Podstawą wykładanego na "nonviolent workshop” światopoglądu była więc chrześcijańska filozofia aktywnej miłości. Te moralne przekonania zostały skonfrontowane z ideami Gandhiego, z którymi Lawson zapoznał się w Indiach. Także King dostrzegł w nauczaniu Mahatmy treści zgodne z nauczaniem Chrystusa. Uważali oni, że odwoływanie się do idei uniwersalnych zasad moralnych, aktywnej miłości oraz walki bez przemocy Gandhiego umożliwi zdobycie dla sprawy większości białych, a bez tego nie byłoby żadnej szansy na sukces. Ich celem ostatecznym była bowiem pełna integracja społeczeństwa, w którym wszyscy ludzie cieszyć się będą wolnością i równością. King pisal: Zanim przeczytatem Gandhiego, uważatem, że etyka Jezusa może mieć zastosowanie tylko w dziedzinie indywidualnych kontaktów między ludźmi. Sądzitem, że

Boga dziatająca w sercach ludzi. Kiedy osiagniesz taki stan, zaczniesz mitować ludzi - nie dlatego, że sq mili, ale dlatego, że Bóg ich kocha. Będziesz mitować każdego cztowieka - nawet najgorszq osobę, jaka znasz - bo wiesz, że mituje go Bóg. Tamże, s. 82.

32 Tami̇e, s. 87.

33 Tamże.

34 M.L. King, Dajcie nam prawa wyborcze, 17 maja 1957, [w:] tenże, „I have a dream”..., s. 71.

35 Tenże, Mitujcie nieprzyjaciót waszych..., s. 88. 
nadstawianie drugiego policzka i mitowanie nieprzyjaciót może mieć sens, gdy jednostka znajduje sie $w$ konflikcie $z$ druga jednostka, natomiast gdy grupy rasowe lub narody popadaja w konflikt, trzeba stosować środki bardziej realistyczne. Jednakże po przeczytaniu książek Gandhiego zrozumiatem, jak wielki byt mój btąd. [...] Nabratem przekonania, że jest to jedyna metoda niebudzaca moralnych zastrzezen, a zarazem skuteczna, jaka dysponuja ludzie uciskani w walce o wolność [...]. Studia nad Gandhim przekonaty mnie, że prawdziwy pacyfizm nie polega na niesprzeciwianiu się ztu, lecz na sprzeciwianiu się ztu bez stosowania gwattu [...]. Polega on na odważnym odpieraniu zta przy pomocy mitości w przekonaniu, że lepiej cierpieć od gwattu niż zadawać gwatt. Stosowanie gwattu powiększa tylko ilośćzta na świecie, podczas gdy przezjego zaniechanie można wzbudzić poczucie wstydu w przeciwniku, zapoczątkowując w ten sposób zmiany w jego sercu ${ }^{36}$.

Fakt, że dwóch protestanckich pastorów odkryło w nauczaniu indyjskiego prawnika treści zgodne z nauką Jezusa, nie powinien dziwić, ponieważ sam Mahatma wskazywał, że wszystkie religie oparte są na tym samym kanonie fundamentalnych wartości moralnych. Uważał on wprawdzie, w odróżnieniu od światopoglądu religijnego, że to moralność jest źródłem religii. Podkreślał, że osnową każdej religii jest prawda i miłość. Człowiek nie może być fałszywy, okrutny i nieznający umiaru, a jednocześnie twierdzić, że ma Boga po swojej stronie. Gandhi był zaniepokojony tym, że wyznawcy różnych religii czczą często tylko symbole (np. krzyż), a ignorują znaczenie podstawowych prawd i wartości moralnych, jak chociażby miłość bliźniego. $Z$ tego względu, gdy pewnego razu padło pytanie, czy jest hinduistą, odpowiedział, że tak, ale równocześnie jest też chrześcijaninem, muzułmaninem, buddystą i żydem.

Postawa polityczna Gandhiego, wyznaczone przez niego cele oraz metody ich realizacji, była rozwinięciem uznawanego przez niego systemu wartości oraz głębokiego przekonania o równości wszystkich ludzi. Pragnął on egalitarnego, opartego na wolności, wzajemnym szacunku, miłości oraz braku jakichkolwiek form przemocy społeczeństwa bezpaństwowego, „oświeconej anarchii”. Będę dziatat na rzecz takich Indii, w których nawet najbiedniejszy będzie czut, że sq one jego krajem, że bierze udziat wich dziejach, będe walczyt o Indie, w których nie będzie kast wyższych i niższych, o Indie, w których wszystkie wyznania będa żyty w idealnej harmonii [...]. W takich Indiach nie będzie miejsca dla przekleństwa niedotykalności [...]. Kobiety będą korzystać z tych samych praw, co mężczyźni [...]. Oto są Indie moich marzeñ ${ }^{37}$.

Warto zwrócić uwagę, że Gandhi walczył nie tylko o niepodległość Indii, ale również o równy status dla niedotykalnych i kobiet, które to grupy były skutecznie wykluczone i dotkliwie dyskryminowane przez prawo i tradycje ${ }^{38}$. Postawa Mahatmy, jego

36 Tenże, Stride Toward Freedom. The Montgomery Story, New York 1964, cyt. za I. Lazari-Pawłowska, Gandhi, Warszawa 1967, s. 205.

37 Wypowiedź Gandhiego przytoczona przez C. Rajagopalachariego, „Young India 10-9-31”, cyt. za J. Justyński, Państwo i prawo w ideologii M.K. Gandhiego, Toruń 1975, s. 24.

38 Hinduizm dzieli ludzi na cztery warny, co miało wynikać z naturalnych różnic między nimi. Warstwa najniższa siudrów rozpadała się na „czystych” i „nieczystych”. Kontakty z „nieczystymi” były zakazane, były naruszeniem zasad religijnych. Gandhi przeciwstawiał się również dotkliwej dyskryminacji kobiet. On sam podziwiał kobiety, ich pasywną siłę, którą utożsamiał z satyagrahą. Z tego względu 
bezkompromisowy egalitaryzm, bez wątpienia mogła być inspiracją dla walczących o zniesienie segregacji rasowej w USA. Warto podkreślić, że w The Civil Rights Movement brały udział kobiety, a wiele z nich, jak Diane Nash, Ruby Doris Smith czy Clara Luper należały do kierownictwa tych organizacji, które współtworzyły ruch ${ }^{39}$.

Dla Gandhiego podstawą jego życia były zasady moralne, prawda i miłość, dlatego uważał, że z żadnego powodu, również tak wzniosłego jak dążenie do stworzenia egalitarnego społeczeństwa bezpaństwowego, nie można ich łamać, szczególnie odwoływać się do nienawiści i przemocy. Powtarzał, że zasada oko za oko uczyniłaby cały świat ślepym. Uważał, że jest możliwe wprowadzenie zmian społeczno-politycznych bez odwoływania się do przemocy, dlatego opracował metodę walki, którą nazwał satyagraha, choć warto dodać, że używał też określenia non-violence. Gandhi tak opisał historię tego terminu: byto rzecza oczywista, że Hindusi sami muszq wynaleźć nowe stowo, które wyrażatoby sens podjętej przez nich walki. Nie mogtem w żaden sposób znaleźć jakiejś nowej nazwy i ogtositem za pośrednictwem "Indian Opinion” konkurs wyznaczajacy nagrodę czytelnikowi, który potrafi ja wymyślec" "40. Słowo satyagraha (satya - prawda oraz agrah - trwać) Gandhi tłumaczył jako „trwać”, „wytrwać w prawdzie” lub „siła prawdy” czy „siła ducha”. Uważał, że jej formą jest zarówno chrześcijański nakaz nadstawiania drugiego policzka, jak i islamski dżihad (oznaczający „dokładać starań”, usilnie dążyć do tego, by być lepszym muzułmaninem). Tradycja nieodwoływania się do przemocy była również głęboko zakorzeniona w hinduizmie i buddyzmie (ahimsa). Ija Lazari-Pawłowska zwróciła uwagę, że w filozofii Gandhiego ahimsa nie ograniczała się jednak wyłącznie do niezabijania i nieranienia, tylko wyrażała aż trzy idee: obronę ludzi przed krzywdą, czyli przeciwdziałanie złu, życzliwość dla przeciwnika oraz walkę bez gwaltu $^{41}$.

Mahatma opisał również, w jaki sposób wygląda ta forma walki. Pierwszym krokiem jest „spojrzenie w lustro”, refleksja nad sobą i przezwyciężenie swoich wad. Satyagraha to osobista postawa, siła ducha. $Z$ tego powodu praktykował on głodówki przed akcjami politycznymi, od 36 roku życia zachowywał celibat i jeden dzień w tygodniu milczał. W ten sposób ćwiczył samodyscyplinę, która dawała mu siłę do działalności politycznej. Widać, że ta idea, iż zmiany należy zacząć od siebie, stała się bezpośrednią inspiracją dla Kinga i Lawsona. Trzeba samemu bezwarunkowo postępować według wartości, które mają stać się podstawą wymarzonego społeczeństwa. Środkiem do

chciał wyeliminować swoją męską seksualność, którą utożsamiał z agresją, i stać się bardziej podobnym do kobiet. Mawiał, że chce być „matką narodu”. Swoją działalnością i apelami wciągnął kobiety w sferę aktywności publicznej, co wcześniej było w tym społeczeństwie nie do pomyślenia. Brały one udział w marszach i akcjach obywatelskiego nieposłuszeństwa. Więcej na temat poglądów i walki Gandhiego $\mathrm{z}$ "przekleństwem niedotykalności” oraz systemem społecznej degradacji kobiet zob. J. Justyński, Państwo i prawo..., s. 21-34.

39 Zob. E. Baker, Women and Community Leadership, [w:] Civil Rights since 1787..., s. 333-340; A.D. Morris, The Origins..., s. 188-193.

40 M.K. Gandhi, Autobiografia. Dzieje moich poszukiwań prawdy, przeł. J. Brodzki, Warszawa 1958, s. 372 .

41 Zob. I. Lazari-Pawłowska, Etyka Gandhiego, Warszawa 1965, s. 31. 
realizacji celów społeczno-politycznych jest aktywna miłość bliźniego, szacunek i bycie wzorem dla innych.

W literaturze naukowej wskazywany jest jeszcze jeden powód, dlaczego przywódcy The Civil Rights Movement nawiązywali do filozofii Gandhiego. Pisząc Stride Toward Freedom. The Montgomery Story (1958), King szukał argumentów, które mogłyby skutecznie przekonać białych czytelników do słuszności motywów osób bojkotujących komunikację miejską w Montgomery. Z tego względu sięgną do dorobku Gandhiego i Henry'ego Davida Thoreau, by - korzystając z ich filozoficznej i wyrafinowanej siatki pojęciowej - móc dotrzeć również do białych studentów i intelektualistów, szczególnie wówczas, gdy wygłaszał odczyty i brał udział w dyskusjach na różnych uniwersytetach ${ }^{42}$.

Oczywiście Lawson i King nie stawiali jako celu stworzenia „oświeconej anarchii”, za optymalną uważali demokrację, która zapewnia wszystkim obywatelom wolność i równość. Wprawdzie w Konstytucji USA zasady te są zapisane, jednak nie były realizowane i to pragnęli oni zmienić. King w kazaniu, które wygłosił w 1957 roku w Montgomery, mówił: Moim zdaniem demokracja jest najlepsza forma rzadów, jaka wymyślit cztowiek. Jej stabość polega jednak na tym, że nigdy jej nie osiagnęliśmy. Czyż nie jest prawdą, że czesto odbieraliśmy podstawowe środki do życia masom, by zapewnić je klasom? Czyż nie jest prawda, że często w naszej demokracji depczemy jednostki i rasy żelazna stopq ucisku? Czyż nie jest prawda, że zachodnie mocarstwa napędzaty kolonializm i imperializm ${ }^{2+3}$.

Prawo, które sankcjonuje segregację rasową i poniża ludzi, jest niesprawiedliwe, dlatego należy je zmienić. Samych protestujących King opisywat jako tych, którzy powstali w obronie amerykańskiego mitu i którzy chcieli przypomnieć Ameryce o wartościach demokracji, której fundamenty zostaty mocno osadzone przez ojców zatożycieli w Deklaracji Niepodlegtości i Konstytucji ${ }^{44}$.

Lawson w wywiadzie udzielonym Robertowi Pennowi Warrenowi deklarował przywiązanie do idei demokratycznego państwa prawa, dlatego, dążąc do realizacji celu, był za każdym razem gotowy, by poddać się wyznaczonej karze ${ }^{45}$. Na wykładach w ramach „nonviolent workshop” tłumaczył studentom, że za pomocą masowych pokojowych protestów, zgodnych z zasadami moralnymi i religijnymi, należy walczyć o społeczeństwo, które oparte będzie na zasadach sprawiedliwości, braterstwa, poszanowania godności każdego człowieka, wolnego od chciwości i biedy.

Lawson zachęcał do aktywnej postawy, ale pozbawionej fizycznej agresji w stosunku do przeciwnika. $Z$ tego względu sama teoria była zdecydowanie niewystarczająca. W czasie warsztatów odwoływał się więc do wcześniejszych doświadczeń, jakie zdobyli Afroamerykanie walczący z przejawami segregacji. Lawson poznał w 1959 roku Cordy’ego Tindella Viviana, który przybył do Nashville, by studiować w American Baptist

Zob. Introduction, [w:] The Papers of Martin Luther King, Jr., vol. 4, s. 31-32.

43 M.L. King, Mitujcie nieprzyjaciót waszych..., s. 79.

44 Tenże, Widze ziemię obiecana, 3 kwietnia 1968, [w:] tenże, „I have a dream”..., s. 187.

45 Zapis rozmowy Robert Penn Warren Rev. J.M. Lawson (Memphis), Tape 1, 3/17/64, [online] http://whospeaks.library.vanderbilt.edu/sites/default/files/RPW.Reel_.2.Rev_.J.M.Lawson.tape_. 1.pg_.797-815.pdf, 17 IV 2017. 
College. Wcześniej, pracując w Peoria, w stanie Illinois, Vivian uczestniczył w 1947 roku w sit-in w Barton's Cafeteria, który doprowadził do zniesienia segregacji w tych lokalach ${ }^{46}$. Lawson na przykładzie tego sit-in pokazywał studentom, jak konkretnie mają wyglądać planowane przez nich akcje. Podkreślał przede wszystkim, że muszą oni być bardzo dobrze zorganizowani. W liście do Kinga z 3 listopada 1958 roku Lawson, odnosząc się do sytuacji ruchu w Birmingham, stwierdził, że szczególnie jedność przywództwa ma decydujące znaczenie ${ }^{47}$. Powtarzał, że nie można iść na demonstrację z ludźmi, którzy nie wykonują konsekwentnie wcześniej założonego planu. Dyscyplina była bezwzględnym warunkiem, by wziąć udział w przeprowadzanych akcjach. „Nonviolent workshop" porównywano z tego powodu do edukacji w samej West Point, ich uczestnicy mówili o sobie, że tworzą armię bez przemocy (Non-violent Army) ${ }^{48}$.

Przeprowadzano też praktyczne ćwiczenia, w czasie których każdy uczestnik musiał doświadczyć ataków słownych i fizycznych, powstrzymując odruch bronienia się czy reagowania agresją. Aktywiści musieli znosić zaczepki i bicie bez gniewu, zachowując godną, wręcz przyjazną postawę $e^{49}$. W ten sposób przygotowywano ich na takie sytuacje w czasie planowanych demonstracji. Wielokrotnie zadawali oni sobie pytania: czy jestem w stanie nadstawić drugi policzek i nie odwzajemnić ciosu? Czy jestem w stanie znieść ciężkie warunki w więzieniu? Lawson w czasie warsztatów powtarzał studentom, że muszą się przygotować na wulgarne wyzwiska, bicie, aresztowanie i tylko ci, którzy się na to godzili, mogli wziąć udział w demonstracji.

W czasie prowadzonych warsztatów pastor Lawson wyznaczył pierwszy cel: zniesienie segregacji w barach działających przy centrach handlowych. Wówczas na Południu Afroamerykanie mogli robić zakupy w sklepach, ale nie mieli prawa spożywać posiłków w znajdujących się przy nich barach. Lawson uważał, że najlepsza strategia to wybór jednego konkretnego celu i konsekwentne dążenie do jego realizacji. W dodatku aktywiści liczyli, że sit-ins $\mathrm{w}$ centrum miasta zostaną zauważone przez prasę, społeczeństwo, władzę.

\section{SIT-INS W NASHVILLE}

Pierwszym krokiem, który podjęli uczestnicy warsztatów, było spotkanie z właścicielami centrów handlowych Fredem Harveyem i Johnem Sloanem, na którym wystosowali prośbę o zmianę regulacji zabraniających obsługiwania Afroamerykanów w barach.

46 A.D. Morris, The Origins..., s. 177. Więcej na temat tego działacza zob. C.T. Vivian Biography, C.T. Vivian Leadership Institute, [online] http://www.ctvli.org/ctvivian.php, 17 IV 2017.

4727 października 1958 roku Lawson pojechał do Birmingham, by wziąć udział w masowym spotkaniu, które zostało zwołane w związku z aresztowaniami pastorów z powodu naruszenia Jim Crow laws dotyczących segregacji w autobusach. Zob. Notes, [w:] From James M. Lawson, 3 November 1958, Nyack N.Y., s. 523.

48 Zob. A Force More Powerful.

49 Szkolenia w podobny sposób były prowadzone przez działaczy CORE, zob. L.E. Lomax, Bunt Murzynów, przeł. K. Dziewanowski, Warszawa 1966, s. 166. 
Obaj odmówili. W związku z tym postanowiono przeprowadzić dwa próbne sit-ins („test lunch counter sit-ins”). 28 października 1959 roku pierwsza grupa studentów zajęła miejsca w Harveys Department Store, kolejna 5 grudnia w Cain-Sloan Store. Właściciele woleli zamknąć bary, niż zezwolić na obsłużenie czarnoskórych studentów. Gazety nie odnotowały na swych łamach tych dwóch wydarzeń.

Na początku 1960 roku doszło do zasadniczego przyspieszenia organizacji protestów $\mathrm{i}$ ich umasowienia. Związane było to $\mathrm{z}$ wydarzeniami z Greensboro w stanie Karolina Północna, które rozniosły się szerokim echem po kraju. 1 lutego 1960 roku w tym mieście o 16.30 czterej studenci - Ezell Blair, Jr., Franklin McCain, Joe McNeil, David Richmond - po zakupach w Woolworth weszli do baru przy tym sklepie, przeznaczonego tylko dla białych, usiedli przy ladach i czekali, aż zostaną obsłużeni. Manager wezwał policję, ale nie zostali oni aresztowani, bo zdaniem policji nie popełnili wykroczenia. Ralph Jones, biały biznesmen syryjskiego pochodzenia, chcąc pomóc studentom, powiadomił prasę, by ta opisała wydarzenia. Historia o tej czwórce (Greensboro Four) w ciągu dnia rozniosła się po mieście i zainspirowała setki studentów, którzy przyłączyli się do akcji. 14 lutego 81 studentów zostało aresztowanych w czasie serii sit-ins. Warto dodać, że ani King, ani SCLC nie zainicjowali sit-ins w Greensboro. Jednak ci młodzi ludzie byli pod wielkim wpływem poglądów i działalności pastora. Ezell Blair, jeden ze studentów, był głęboko poruszony jego przemową wygłoszoną w Greensboro’s Bennett College ${ }^{50}$.

Oczywiście czwórka z Greensboro nie wymyśliła tej formy protestu. Sit-ins były już wcześniej popularne wśród aktywistów związków zawodowych. W Chicago w 1940 roku Congress of Racial Equality (CORE) przeprowadzał akcje typu $s_{i t-i n^{51}}$. Pod koniec lat 50. jego członkowie organizowali sit-ins oraz warsztaty o bezpośrednich akcjach bez użycia przemocy (najbardziej znane to September Action Institute; w jednym z nich w Miami brał udział King $)^{52}$. Sit-ins były przeprowadzane również przez NAACP Youth Council ${ }^{53}$. W Greensboro liderem tej organizacji był Floyd McKissick, który już w 1957 roku przeprowadził sit-in w Durham’s Royal Ice Cream Parlor, zakończony sukcesem - zniesiono w tej sieci segregację rasową (sprawa stała się znana jako „Royal Ice Cream Case”) ${ }^{54}$. W latach 1957-1960 CORE, NAACP YC i SCLC

50 Więcej na ten temat zob. Introduction, [w:] The Papers of Martin Luther King, Jr., vol. 5: Threshold of a New Decade, January 1959-December 1960, red. T. Armstrong i in., Berkeley 2005, s. 11.

51 CORE zostało utworzone w marcu 1942 roku przez grupę studentów University of Chicago. Wielu założycieli było członkami FOR (Fellowship of Reconciliation). Odwoływali się oni do filozofii Gandhiego i propagowali jego metodę walki bez przemocy. Pierwotna nazwa to Committee on Racial Equality. Więcej na temat CORE i jej zaangażowania w The Civil Rights Movement zob. Congress of Racial Equality, [w:] King Encyclopedia, The Martin Luther King, Jr., Research and Education Institute, [online] https://kinginstitute.stanford.edu/encyclopedia/congress-racial-equality-core, 17 IV 2017; M. Viorst, CORE and the Pacifist Roots of Civil Rights, [w:] Civil Rights since 1787..., s. 428-434.

52 Więcej na temat licznych sit-ins w latach 50. zob. A.D. Morris, The Origins..., s. 190-193; Introduction, [w:] The Papers of Martin Luther King, Jr., vol. 4, s. 38.

53 NAACP Youth Council było powstałym w 1935 roku odgałęzieniem NAACP.

54 Floyd McKissick był pierwszym afroamerykańskim studentem na University of North Carolina at Chapel Hill's Law School (UNC). Gdy aplikowal na ten uniwersytet, odrzucono jego wniosek ze 
zorganizowały w co najmniej 16 miastach bojkoty oraz akcje typu sit-in. Zdaniem Morrisa wcześniejsze sit-ins nie były jednak siłą napędową masowego ruchu, dopiero wydarzenia z Greensboro nadały nowy impuls walce z segregacją rasową ${ }^{55}$. Wiadomości o tej akcji rozprzestrzeniły się na Południu bardzo szybko i studenci college'ów masowo przystąpili do dotychczasowych aktywistów, zwanych old movement warriors ${ }^{56}$. Między 1 lutego (Greensboro) a 1 kwietnia 1960 roku w 70 miastach Południa odbywały się sit-ins.

Kiedy do Nashville dotarły wieści o wydarzeniach z Greensboro, na „nonviolent workshop" pojawiło się aż około 500 nowych osób. Studenci 13 lutego postanowili rozpocząć akcję․ Lawson w wywiadzie udzielonym Robertowi Pennowi Warrenowi wspominał, że choć przygotowywał to wydarzenie, to jednak sam nie brał w nim udziału, był w tym czasie poza miastem ${ }^{58}$. Właściciele barów ponownie je zamknęli, a prasa nie odnotowała jako istotnego tego wydarzenia. Lawson dodał, że wcześniej aktywiści poinformowali policję o zamierzonych działaniach i wszystko przebiegło bardzo spokojnie, bez bójek czy aresztowan ${ }^{59}$. Kolejną akcję zaplanowano na 28 lutego. Dzień wcześniej policja powiadomiła pastora, że na prośbę właścicieli barów oraz zgodnie z wytycznymi otrzymanymi od burmistrza Bena Westa, jeśli studenci podejmą akcję, będą aresztowani ${ }^{60}$. Pastor na spotkaniu przed akcją powiedział aktywistom, że następnego dnia, jeśli chcą oni wziąć udział w sit-in, muszą być gotowi na pobicia i aresztowania. Mimo to, nie mogą w tych chwilach zapominać o ideach Jezusa, Gandhiego i Kinga, więc w żadnym wypadku nie powinni odpowiadać przemocą czy nieuprzejmością. Ustalono dress code: aktywiści mieli być ubrani schludnie w białe koszule i zachowywać się bardzo spokojnie, kulturalnie, czytać i odrabiać zadania ${ }^{61}$. Lawson podzielił ich na kilka grup, które miały zastępować aresztowanych na miejscach przy ladach. 28 lutego studenci zajęli miejsca i oczywiście nie zostali obsłużeni. W krótkim czasie pojawili się biali młodzieńcy, którzy zaczęli ich prowokować i dopuścili się aktów przemocy fizycznej. Następnie wkroczyła policja, która najpierw wezwała studentów do opuszczenia

względu na jego rasę. Musiał więc podjąć studia na uniwersytecie dla Afroamerykanów w Durham. Jego sprawą zainteresowało się NAACP i wniosło pozew przeciw UNC. W 1951 roku Sąd Apelacyjny USA wydał nakaz przyjęcia McKissicka i trzech innych studentów na UNC's Law School. Więcej na jego temat zob. Floyd B. McKissick, CORE, [online] http://www.core-online.org/History/ mckissick.htm, 17 IV 2017. Zob. A.D. Morris, The Origins..., s. 193.

Zob. tamże, s. 195.

Zob. Ch.M. Richardson, R.E. Luker, Historical Dictionary..., s. 20.

Zob. zapis rozmowy Robert Penn Warren Rev. J.M. Lawson (Memphis), Tape 1...

Zob. zapis rozmowy Robert Penn Warren Rev. J.M. Lawson (Memphis), Tape 2, 3/17/64, [online] http://whospeaks.library.vanderbilt.edu/sites/default/files/RPW.Reel_.2.Rev_J.M.Lawson. tape_.2.pg_.816-837.pdf, 17 IV 2017.

60 Raphael Benjamin West (1911-1974), prawnik i polityk, który w latach 1949-1951 był senatorem, a w latach 1951-1963 burmistrzem Nashville. Więcej na jego temat zob. D.H. Doyle, Ben West, [w:] The Tennessee Encyclopedia of History and Culture, [online] http://tennesseeencyclopedia.net/entry. php?rec=1492.

Zob. M. Viorst, Fire in the Streets. America in the 1960s, New York 1979, s. 130. 
baru, a z powodu braku reakcji wszystkich aresztowała. Na ich miejsce pojawili się od razu studenci z kolejnej grupy. Policjanci nie byli na to przygotowani, nie wiedzieli, co robić. Tymczasem kolejna grupa czekała już, by w razie aresztowań ponownie obsadzić miejsca przy ladach. Po godzinie zaprzestano aresztowań. Zgodnie z wcześniejszymi ustaleniami, studenci odmówili wyjścia za kaucją. Ten sit-in był wielkim sukcesem, ponieważ aktywistom udało się skupić uwagę prasy oraz opinii publicznej. Biały dziennikarz John Seigenthaler z „The Nashville Tennessean” relacjonował później, że choć początkowo podchodził do sit-in jak do żartu („co ta młodzież sobie wyobraża”), to z czasem zaczął zdawać sobie sprawę, że toczy się wojna, wojna bez przemocy. Była to dla niego nowa, niespotykana forma, więc nie wiedział, jak opisywać te wydarzenia, ale - jak mówil - czuł się niczym korespondent wojenny ${ }^{62}$.

Społeczność była poruszona tym, że młodzi, kulturalnie zachowujący się studenci zostali aresztowani. Zorganizowano zbiórkę pieniędzy na adwokatów. Istotne jest to, że cała sytuacja wywołała zainteresowanie i oburzenie dużej części białej społeczności, która również wsparła ruch. Obrońcami zostali jeden z wybitniejszych czarnoskórych prawników Zephaniah Alexander Looby (współpracujący z NAACP już od dłuższego czasu), Avon Nyanza Williams i Robert E. Lillard. Nie udało im się jednak przekonać sądu i ten skazał każdego ze studentów na wysoką grzywnę w wysokości 150 dolarów oraz opłatę kosztów sądowych. Wielu nie było stać na ten wydatek, pospieszyła więc z pomocą społeczność, zbierając na to fundusze.

3 marca 1960 roku za zaangażowanie w organizację sit-ins Lawson został wydalony z Vanderbilt Divinity School. Tego samego dnia aresztowano go wraz z innymi studentami. Jego usunięcie ze szkoły wywołało protesty studentów oraz krytykę ze strony innych uniwersytetów, co doprowadziło do rezygnacji dziekana i członków tego wydziału $^{63}$. Ostatecznie Vanderbilt zaproponowało Lawsonowi przywrócenie, jednak on wybrał Boston University i tam uzyskał tytuł w tym samym roku. King określał go jako gtównego teoretyka i stratega walki bez przemocy na świecie $e^{64}$.

W kwietniu 1960 roku Lawson przyczynił się do stworzenia Student Nonviolent Coordinating Committee (SNCC) w czasie konferencji w Raleigh w Karolinie Północnej. Organizacja ta miała, w przeciwieństwie chociażby do NAACP, ukierunkowywać aktywistów na podejmowanie działań bezpośrednich, takich jak sit-ins, bojkoty, marsze pokojowe ${ }^{65}$. Lawson, który z powodzeniem prowadził „nonviolent workshop”,

62 Zob. A Force More Powerful.

63 Zob. Ch.M. Richardson, R.E. Luker, Historical Dictionary..., s. 279. W 2005 roku Vanderbilt, pragnąc zadośćuczynić, nadało Lawsonowi tytuł Distinguished Alumnus i zaprosiło go w 2006 roku do Nashville jako Distinguished University Professor.

64 Lawson uzyskat tytuł S.T.B. (The Bachelor of Sacred Theology, łac. Sacrae Theologiae Baccalaureus). Więcej na ten temat zob. C. Daniloff, A Short Stay, Long in Memory, „Bostonia” Summer 2008, [online] http://www.bu.edu/bostonia/summer08/short-stay/, 17 IV 2017.

65 W czasie przemówienia na tej konferencji Lawson skrytykował NAACP za to, że swoje działania opiera tylko na drodze prawnej, sporach sądowych i lobbowaniu. Dziennikarz z „New York Timesa” opisał, że Lawson na konferencji określił NAACP jako „black bourgeois club” i ,fund-raising agency”. Pastor wyraził pogląd wielu członków ruchu. King także sympatyzował ze stanowiskiem Lawsona, ponieważ uważał, że to bezpośrednie akcje, a nie spory sądowe, mają szanse przyczynić się do zniesienia 
stał się autorytetem dla studentów, postrzegających go jako naturalnego przywódcę, częściej nawet niż Kinga ${ }^{66}$. Poproszono go, by sformułował cele filozoficzne i praktyczne dla SNCC, przygotował więc zwięzłą wykładnię zasad filozofii Gandhiego, która stała się oficjalnym dokumentem programowym ${ }^{67}$.

King wyrażał swoje wsparcie dla uczestników sit-ins, ale był tą akcją z początku 1960 roku zaskoczony i nie podją się jej kierownictwa. Wynikało to z tego, że wówczas sam miał problemy z porozumieniem się ze współpracownikami z SCLC co do taktyki działań, w dodatku był pochłonięty swoją obroną przed zarzutem krzywoprzysięstwa, które mogło zszargać jego reputację ${ }^{68}$.

W Nashville, kontynuując walkę o zniesienie segregacji, zorganizowano bojkot sklepów. W ten sposób chciano dać szerszym grupom ludności możliwość wsparcia ruchu. Agitowano w centrum, więc biali unikali tych miejsc, mimowolnie przyłączając się do bojkotu. W mieście zrobiło się pusto na ulicach, co sprawiało niesamowite wrażenie. Przed Wielkanocą, zamiast tradycyjnego szału zakupów, obroty bojkotowanych sklepów spadty o $20 \%{ }^{69} .19$ kwietnia o poranku doszło do zamachu bombowego na dom Zephaniaha Alexandra Looby'ego - obrońcy studentów. Członkowie Ku Klux Klanu wcześniej też podpalali domy innych aktywistów ${ }^{70}$. Na szczęście członkowie rodziny Looby'ego odnieśli tylko niewielkie obrażenia. W odpowiedzi studenci zorganizowali tego dnia cichy marsz, do którego przyłączyli się mieszkańcy miasta, również biali, potępiający te bulwersujące akty przemocy. Szacuje się, że w marszu wzięło udział około 2500 osób. Protestujący dotarli do Nashville’s City Hall, gdzie Diane Nash, jako przedstawicielka protestujących, poprosiła burmistrza Bena Westa, by zajął stanowisko nie tylko wobec zamachu, ale i praktyk segregacyjnych w miejscach użyteczności publicznej. Burmistrz stwierdził, że są to niesprawiedliwe praktyki. Były to niezwykle ważne słowa, które zapoczątkowały zmiany. Ben West powołał komisję złożoną z białych i czarnych, która zawarła kompromis, że właściciele barów kończą z polityką segregacji,

segregacji. Lawson starał się później złagodzić nieporozumienia, wysyłając 9 maja do lidera NAACP Roya Wilkinsa (piastował to stanowisko w latach 1955-1977) list, w którym podkreślał swoje związki $\mathrm{z}$ tą organizacją. Więcej na temat tych nieporozumień między liderami The Civil Rights Movement zob. Introduction, [w:] The Papers of Martin Luther King, Jr., vol. 5, s. 14. foundation of our purpose, the presupposition of our faith, and the manner of our action. Nonviolence as it grows from Judaic-Christian traditions seeks a social order of justice permeated by love. James Lawson, Statement of purpose, 17 April 1960, [online] https://kinginstitute.stanford.edu/sites/default/files/ publications/vol5intro.pdf, 17 IV 2017.

68 W lutym 1960 roku postawiono Kingowi zarzuty o podpisanie sfałszowanego dokumentu dotyczącego zwrotu podatku z lat 1956 i 1958. Proces rozpoczą się 25 maja 1960 roku w Montgomery, Alabama. Ostatecznie ława przysięgłych złożona z samych białych uniewinniła Kinga, zob. State of Alabama $v$. M.L. King, Jr., Nos. 7399 and 9593, [online] https://kinginstitute.stanford.edu/encyclopedia/statealabama-v-m-l-king-jr-nos-7399-and-9593, 17 IV 2017. encyclopedia.net/entry.php?rec=1210, 17 IV 2017.

Zob. I. Rusinowa, Martin Luther King..., s. 138. 
ale protestujący nie będą ogłaszać końca bojkotu i zwycięstwa. 10 maja 1960 roku Nashville stało się pierwszym miastem Południa, w którym zniesiono segregację w miejscach publicznych.

Ruch z Nashville stał się modelem dla całego The Civil Rights Movement. King, jak zacytowano na wstępie, również był pod wrażeniem tego, co wydarzyło się w tym mieście. W odróżnieniu chociażby od Greensboro, w którym akcja była spontaniczna, w Nashville cały ruch był niezwykle dobrze przygotowany. Od 1958 roku Lawson prowadził warsztaty, na których wskazywał idee mające lec u podłoża tych działań, a następnie przeprowadzał praktyczne ćwiczenia ${ }^{71}$. Od 13 lutego do 10 maja 1960 roku odbywały się akcje sit-ins w barach i restauracjach domów towarowych, bojkot sklepów i masowy cichy marsz ${ }^{72}$. Te wszystkie elementy doprowadzity do sukcesu, a wielu członków warsztatów z Nashville stało się liderami ogólnokrajowego ruchu.

\section{JAMES LAWSON - KRÓTKA CHARAKTERYSTYKA PÓŹNIEJSZEJ DZIAŁALNOŚCI}

Sam James Lawson również dalej angażował się w działalność The Civil Rights Movement. W latach 1960-1967 był przewodniczącym sekcji edukacji strategii walki bez przemocy w SCLC (director of nonviolent education). W latach 1960-1964 był doradcą SNCC. Pomógł zorganizować Freedom Ride, który odbył się 4 maja 1961. Wziął w nim udział razem z przedstawicielami CORE i SNCC. Wraz z innymi aktywistami trafił do więzienia, a po wyjściu zostali oni dotkliwie pobici przez grupę białych mężczyzn $^{73}$. W 1962 roku Lawson został pastorem w Centenary Methodist Church w Memphis. W tym czasie pomagał Kingowi zarówno planować, jak i wykonać plan (prowadził znów warsztaty) walki z segregacją w Birmingham ${ }^{74}$. W 1968 roku doradzał grupie strajkujących Afroamerykanów ze służb sanitarnych miasta (sanitation workers). Zaprosił Kinga do Memphis, by ten pomógł w organizacji strajku. King przybył i wygłosił swoje słynne przemówienie „Mountaintop” w dzień przed zamachem na jego życie. Po zabójstwie Kinga Lawson został jeszcze 6 lat w Memphis, potem przeprowadził

71 Lawson napisat w gazecie, że nowy ruch mtodzieży jest skierowany przeciwko nie tylko segregacji rasowej, lecz również stanowisku wielu Murzynów typu Uncle Tom pragnacych zachowania spokoju i możliwości bogacenia się, przeciwko dziataczom NAACP i jatowemu wysytaniu przez murzyńską klasęśrednia listów do centrów wtadzy z jakimiś dotykającymi ich protestami, czy też przeciwko sądom amerykańskim zbyt powolnie rozstrzygajacym sprawy o segregacje rasowa. Tamże, s. 141.

72 Zob. L.T. Wynn, Sit-ins...; taż, The Dawning of a New Day. The Nashville Sit-Ins, February 13-May 10, 1960, „Tennessee Historical Quarterly” 1991, vol. 50, s. $42-54$.

73 Biali i czarni studenci podróżowali wspólnie autobusami międzystanowymi, próbując przełamać segregację rasową w tych pojazdach. Dodać należy, że - jak już wspomniano we wstępie niniejszego artykułu - ta forma segregacji była niezgodna z prawem. Więcej na ten temat zob. Ch.M. Richardson, R.E. Luker, Historical Dictionary..., s. 21-22.

74 Sit-ins w Birmingham rozpoczęly się 3 kwietnia 1963 roku. 12 kwietnia doszło do aresztowań, między innymi Kinga. Te wydarzenia były bezpośrednim bodźcem zorganizowania Marszu na Waszyngton, w czasie którego King wygłosił słynną mowę I have a dream. Zob. tamże, s. 22-25. 
się do Los Angeles. Nie porzucił swej aktywności, między innymi szkolił tych, którzy przeciwstawiali się wojnie z Irakiem czy chcieli walczyć o prawa dla imigrantów albo prawa pracy. Dzisiaj jest emerytowanym pastorem Holman United Methodist Church w Los Angeles.

\section{METODA WALKI O ZMIANY SPOŁECZNO-POLITYCZNE - KILKA UWAG}

King w kazaniu Mitujcie nieprzyjaciót waszych mówił: Dzisiaj nasz świat znajduje się $w$ przetomowym momencie. Caty świat stoi w obliczu rewolucji. Nasz kraj stoi w obliczu rewolucji ${ }^{75}$. Postawił on diagnozę, że oparty na imperializmie i kolonializmie porządek polityczny na świecie, jak również system społeczno-polityczny USA, nie mogą już dłużej funkcjonować w dotychczasowym kształcie. Oparte są one na przemocy, niesprawiedliwości, wyzysku i dyskryminacji ludzi, które prowadzą nieuchronnie do degeneracji moralnej zarówno rządzących, jak i rządzonych. Wprawdzie panował w tych warunkach pokój, ale był to pokój negatywny. Prawdziwy pokój nie polega bowiem na braku negatywnych sit - napięc, chaosu, wojny, lecz na obecności sit pozytywnych - sprawiedliwości, dobrej woli i braterstwa ${ }^{76}$. Polityka w przekonaniu Kinga powinna opierać się na moralnych, uniwersalnych wartościach. Uważał on, że obowiązkiem każdego religijnego człowieka, szczególnie pastora, jest wskazywanie na istniejące w świecie niesprawiedliwości i mobilizowanie ludzi, by dążyli do zmiany tego stanu rzeczy. Jak powtarzał, moralne działanie charakteryzuje się niewspieraniem zła, dlatego aktywność polityczna, dokonanie rewolucji, staje się indywidualnym zobowiązaniem moralnym. To przekonanie motywowało nie tylko Kinga czy Lawsona, ale większość przywódców i działaczy The Civil Rights Movement, którzy byli ludźmi religijnymi, a głównym miejscem ich spotkań były kościoły.

Warto wskazać powody tego, że przełom lat 50. i 60. stał się początkiem rewolucji. Sam King nieustannie zwracał uwagę przede wszystkim na rosnącą samoświadomość Murzynów, to w niej upatrywał źródła zmian. Warto przytoczyć jego słowa z artykułu z 6 lutego 1957 roku opublikowanego na łamach tygodnika religijnego „Christian Century”: Z tatwościa można zauważý, że kryzys na tle rasowym zdominowat amerykańska codzienność. Na szybki rozwój tego kryzysu wptynęty dwa czynniki: zdecydowany sprzeciw reakcyjnych elementów na Potudniu wobec przetomowej decyzji Sądu Najwyższego zakazujacej segregacji w szkotach publicznych oraz diametralna zmiana w samoocenie Murzynów. [...] w sposobie, w jaki Murzyni postrzegaja wtasna naturę i przeznaczenie, zaszta rewolucyjna zmiana. W przesztości uważali się za gorszych, cierpliwie tolerując niesprawiedliwość i wyzysk. Te dni minęty ${ }^{77}$.

\footnotetext{
75 M.L. King, Mitujcie nieprzyjaciót waszych..., s. 86.

76 Tenże, Strategia non-violence a sprawiedliwość rasowa, s. 26.

77 Tamże, s. 25.
} 
Można więc sformułować tezę, że według Kinga rewolucja zaczyna się w człowie$\mathrm{ku}$, gdy zmienia on postrzeganie siebie i zauważa dysonans między swoją naturą a zewnętrznym porządkiem. Dzięki religii Afroamerykanie uświadomili sobie, że są równi, bo Bóg kocha tak samo wszystkie swoje dzieci. Rozbudziło się w nich również pragnienie wolności. Determinacja amerykańskich Murzynów w walce o uwolnienie ze wszelkich form ucisku wynika z tej samej gtębokiej tęsknoty za wolnościa, która motywuje do buntu wszystkich ciemiężonych na catym świecie ${ }^{78}$. Zastanawiając się nad przyczynami tej rewolucyjnej zmiany świadomości, obok religii, King wskazał na poprawę ich sytuacji ekonomicznej oraz coraz szerszy dostęp do edukacji ${ }^{79}$. Diane Nash, studiująca na Fisk University, w jednym z wywiadów opowiadała, że na zajęciach uczono ich o Konstytucji i zapisanych w niej zasadach głoszących wolnossć i równość ludzi, a następnie szli do miasta i w upadlający sposób wskazywano im, że są gorsi i dlatego powinni żyć oddzielnie $^{80}$. Afroamerykanie uświadamiali sobie hipokryzję systemu: demokracja wcale nie była demokracją. Warto w tym miejscu przytoczyć refleksję Jürgena Habermasa, teoretyka Nowej Lewicy, który w Filozoficznym dyskursie nowoczesności skonstruował narrację rozwoju społeczeństwa Zachodu i postawił wniosek o rozszerzających się nożycach pomiędzy tym, co wiemy, a tym, jak społeczeństwa faktycznie egzystują ${ }^{81}$.

Warto podkreślić też rolę intelektualistów w inspirowaniu i kształtowaniu nowej samoświadomości Afroamerykanów, szczególnie nowego pokolenia. Tę rewolucję przeprowadzili bowiem młodzi ludzie, przede wszystkim studenci college’ów. Ich przywódcy nie byli zresztą wiele starsi: King w 1960 roku miał 31 lat, Lawson 32 lata. To młodzieńczy idealizm oraz poczucie wspólnoty dawało im siłę, by podjąć ryzyko, godzić się na pobicia i aresztowania - przeprowadzić rewolucję ${ }^{82}$.

Powiodła się ona dzięki tym młodym ludziom, ale warunkiem koniecznym było zaangażowanie w ruch i uzyskanie przychylności większości społeczeństwa, w tym oczywiście białych.

\section{Tamże, s. 26.}

79 Między 1950 a 1970 rokiem zatrudnienie Afroamerykanów w pracach white-collar jobs wzrosło z 8 do 19\%, wśród kobiet z 11 do 36\% zatrudnienia. Zob. A.D. Morris, The Origins..., s. 34. Warto zwrócić uwagę, że polaryzacja sytuacji ekonomicznej między Afroamerykanami od 1960 roku stopniowo zaczęła się pogłębiać. Zob. M.C. Dawson, Behind the Mule. Race and Class in African-American Politics, Princeton 1994, s. 9.

80 Tomasz Jefferson, 25 lat po uchwaleniu Konstytucji, zapisał 24 czerwca 1826 roku taką refleksję: Ta forma, która myśmy ustanowili, przywrócita wolne prawa nieskrępowanego używania rozumu i wolności opinii. Oczy catego świata zwrócone sa lub zwracaja się teraz ku prawom cztowieka. Powszechny postęp świata $i$ wiedzy uświadomit każdemu namacalna prawdę, że masy ludzkie nie urodzity się z siodtami na grzbietach, nieliczni zaś uprzywilejowani nie otrzymali z taski Boga butów i ostróg do ich ujeżdżania. Oto fundament nadziei dla innych. Cyt. za: Z. Libiszowska, Tomasz Jefferson, Wrocław 1984, s. 9. Można skonstatować, że faktycznie Konstytucja również ponad 100 lat później nadal stanowiła „fundament nadziei”, że zasady w niej zapisane obejmą wszystkich mieszkańców USA.

To the students themselves, the experience was nothing less than exhilarating. John Lewis had been scared before the first sit-in. There were two things which helped him get through. The first was, his absolute certainly that what they were doing was right. The second was that he was not alone. He was with his friends, the closests friends he had ever had in his life. D. Halberstam, The Children, New York 1998, s. 105. 
W wywiadach ze świadkami tych wydarzeń przykuło mą uwagę stwierdzenie białego dziennikarza Johna Seigenthalera: $w$ tym czasie miasto byto posegregowane jak RPA w czasach najgtębszego apartheidu $i$ wydawato się z tego zadowolone $e^{83}$. Taka postawa ma uniwersalny wymiar. Oprawcy zazwyczaj zadowoleni są ze swej dominującej pozycji i nie postrzegają tego typu relacji jako problem. Zdziwienie, gdy głos podnoszą różne dyskryminowane grupy, jest więc autentyczne.

Społeczność wsparła jednak studentów, ponieważ była poruszona tym, że ta kulturalna młodzież została aresztowana. Unaoczniona została niesprawiedliwość systemu. Wprawdzie była ona codziennością, jednak ten protest wyolbrzymił i skupił oczy wszystkich w mieście na tym problemie. Istotne jest to, że cała sytuacja wywołała zainteresowanie i oburzenie dużej części białej społeczności. Dzięki działaniu bez przemocy nie można było zarzucić protestującym łamania zasad moralnych. Biali także zaczęli dostrzegać kontrast między prawem a zasadami moralnymi i część z nich uznała postulat zmiany prawa za słuszny. Walka bez przemocy, którą wybrali King, Lawson i inni przywódcy ruchu, wynikała z przekonania, że środki polityczne muszą być odpowiednie do celów, to znaczy tak samo moralne. Dzięki tej metodzie zdobyli oni wsparcie społeczeństwa, które wyznawało przecież ten sam chrześcijański system wartości moralnych.

\section{BIBLIOGRAFIA}

Daniloff C., A Short Stay, Long in Memory, „Bostonia” Summer 2008, [online] http://www. bu.edu/bostonia/summer08/short-stay/.

Baker E., Women and Community Leadership, [w:] Civil Rights since 1787. A Reader on the Black Struggle, red. J. Birnbaum, C. Taylor, New York-London 2000.

The Cambridge History of American Theatre, vol. 1: Beginnings to 1870, red. D.B. Wilmeth, Ch. Bigsby, Cambridge 1998.

Congress of Racial Equality, [w:] King Encyclopedia, The Martin Luther King, Jr., Research and Education Institute, [online] https://kinginstitute.stanford.edu/encyclopedia/congressracial-equality-core.

C.T. Vivian Biography, C.T. Vivian Leadership Institute, [online] http://www.ctvli.org/ctvivian.php.

Dawson M.C., Behind the Mule. Race and Class in African-American Politics, Princeton 1994.

Doyle D.H., Ben West, [w:] The Tennessee Encyclopedia of History and Culture, [online] http:// tennesseeencyclopedia.net/entry.php?rec=1492.

Fellowship of Reconciliation, [online] http://www.forusa.org.

Floyd B. McKissick, CORE, [online] http://www.core-online.org/History/mckissick.htm.

Frazier F.E., The Negro Church in America, New York 1963.

Gandhi M.K., Autobiografia. Dzieje moich poszukiwań prawdy, przeł. J. Brodzki, Warszawa 1958. Halberstam D., The Children, New York 1998.

83 Zob. A Force More Powerful. 
Jim Crow America. A Documentary History, red. C.M. Lewis, J.R. Lewis, Fayetteville 2009.

Justyński J., Państwo i prawo w ideologii M.K. Gandhiego, Toruń 1975.

King M.L., „I have a dream”. Stowa zburzyty mury, przeł. G. Kość, G. Zawora, red. B. Szklarski, P. Średziński, Warszawa 2014.

King M.L., Stride Toward Freedom. The Montgomery Story, New York 1964.

Kuumba B.M., Gender and Social Movements, Walnut Creek 2001.

Lazari-Pawłowska I., Etyka Gandhiego, Warszawa 1965.

Lazari-Pawłowska I., Gandhi, Warszawa 1967.

Libiszowska Z., Tomasz Jefferson, Wrocław 1984.

Lomax L.E., Bunt Murzynów, przeł. K. Dziewanowski, Warszawa 1966.

Modzelewski W., Walka bez użycia przemocy. Metody i idee, Warszawa 1983.

Morris A.D., The Origins of the Civil Rights Movement. Black Communities Organizing for Change, New York 1986.

National Association for the Advancement of Colored People, [online] http://www.naacp.org/ oldest-and-boldest/.

The Papers of Martin Luther King, Jr., vol. 4: Symbol of the Movement, January 1957-December 1958, red. C. Carson i in., Berkeley 2000.

The Papers of Martin Luther King, Jr., vol. 5: Threshold of a New Decade, January 1959-December 1960, red. T. Armstrong i in., Berkeley 2005.

Richardson Ch.M., Luker R.E., Historical Dictionary of the Civil Rights Movement, Lanham 2014.

Rusinowa I., Martin Luther King Jr. 1929-1968, Pułtusk-Warszawa 2014.

Rusinowa I., Martin Luther King Junior i wydarzenia w Montgomery, [w:] Amerykomania. Ksiega jubileuszowa ofiarowana profesorowi Andrzejowi Mani, t. 2, red. W. Bernacki, A. Walaszek, Kraków 2012.

Sitkoff H., The Struggle for Black Equality, New York 1993.

Smith, Kelly Miller, [w:] King Encyclopedia, The Martin Luther King, Jr., Research and Education Institute, [online] https://kinginstitute.stanford.edu/encyclopedia/smith-kelly-miller.

SCLC History, Southern Christian Leadership Conference, [online] http://nationalsclc.org/ about-us/history/.

Sullivan P., Charles Hamilton Houston and the NAACP Legal Strategy, [w:] Civil Rights since 1787. A Reader on the Black Struggle, red. J. Birnbaum, C. Taylor, New York-London 2000.

Viorst M., CORE and the Pacifist Roots of Civil Rights, [w:] Civil Rights since 1787. A Reader on the Black Struggle, red. J. Birnbaum, C. Taylor, New York-London 2000.

Viorst M., Fire in the Streets. America in the 1960s, New York 1979.

Węgrzecki J., Wptyw, autorytet, dominacja. Teorie wtadzy i ich struktura, Warszawa 2011.

Wynn L.T., Sit-ins, Nashville, [w:] The Tennessee Encyclopedia of History and Culture, [online] https://tennesseeencyclopedia.net/entry.php?rec $=1210$.

Wynn L.T., The Dawning of a New Day. The Nashville Sit-Ins, February 13-May 10, 1960, „Tennessee Historical Quarterly” 1991, vol. 50.

Zinn H., Ludowa historia Stanów Zjednoczonych. Od roku 1492 do dziś, przeł. A. Wojtasik, Warszawa 2016. 


\section{Dokumenty:}

A Force More Powerful (polski tytuł: Sita bez przemocy), documentary film, written \& produced by Steve York, release 1999 and 2000, York Zimmerman INC\&WETA, Washington, DC.

Brown v. Board of Education of Topeka, 347 U.S. 483 (1954), [online] https://supreme.justia. com/cases/federal/us/347/483/case.html.

The Civil Rights Act, [online] http://library.clerk.house.gov/reference-files/PPL_CivilRightsAct_1964.pdf.

King to Smith, 9 June 1960, [online] https://kinginstitute.stanford.edu/king-papers/docu ments/kelly-miller-smith-1.

Lawson, James, Statement of purpose, 17 April 1960, [online] https://kinginstitute.stanford. edu/sites/default/files/publications/vol5intro.pdf.

Plessy v. Ferguson, 163 U.S. 537 (1896), [online] https://supreme.justia.com/cases/federal/ us/163/537/case.html.

State of Alabama v. M.L. King, Jr., Nos. 7399 and 9593, [online] https://kinginstitute.stanford. edu/encyclopedia/state-alabama-v-m-l-king-jr-nos-7399-and-9593.

The Voting Rights Act, [online] http://library.clerk.house.gov/reference-files/PPL_VotingRightsAct_1965.pdf.

Zapis rozmowy Robert Penn Warren Rev. J.M. Lawson (Memphis), Tape 1, 3/17/64, [online] http://whospeaks.library.vanderbilt.edu/sites/default/files/RPW.Reel_.2.Rev_.J.M.Lawson.tape_.1.pg_.797-815.pdf.

Zapis rozmowy Robert Penn Warren Rev. J.M. Lawson (Memphis), Tape 2, 3/17/64, [online] http://whospeaks.library.vanderbilt.edu/sites/default/files/RPW.Reel_.2.Rev_.J.M.Lawson.tape_.2.pg_.816-837.pdf.

Marta BARANOWSKA - dr hab. nauk prawnych, profesor Uniwersytetu Mikołaja Kopernika w Toruniu na Wydziale Prawa i Administracji. Jej zainteresowania naukowe koncentrują się na doktrynach polityczno-prawnych, historii myśli politycznej i filozofii polityki. Autorka monografii Jednostka, państwo i prawo w filozofii Fryderyka Nietzschego. Mata vs wielka polityka, Wydawnictwo Naukowe UMK, Torun 2009, oraz Cel uświęca środki, czyli Niccolò Machiavellego rozważania o wtadzy, Wydawnictwo Naukowe UMK, Toruń 2018. 